A N N A L ES

UNIVERSITATIS MARIAE CURIE-SKŁODOWSKA

LUBLIN - POLONIA

VOL. LXIII, 2

SECTIO G

2016

Uniwersytet Marii Curie-Skłodowskiej w Lublinie

elizakosieradzka@poczta.umcs.lublin.pl

marian.zdyb@poczta.umcs.lublin.pl

ELIZA KOMIERZYŃSKA, MARIAN ZDYB

\title{
Klauzula interesu publicznego w działaniach administracji publicznej
}

Public Interest Clause in Public Administration Activity

Współcześnie, przy podejmowaniu prób zdefiniowania pojęcia administracji publicznej czy też wyznaczenia jej znamion (cech charakterystycznych, typowych, podstawowych), znamienne jest sięganie do kategorii interesu publicznego jako elementu charakteryzującego jej istotę. Już na wstępie należy zaznaczyć, że interes publiczny „nie ma generalnego, wszechobejmującego znaczenia opisowego, jego znaczenie opisowe związane jest z kontekstem społecznym i politycznym".

Od dawna zauważa się, że pojęcie interesu (w tym interesu publicznego) zajmuje doniosłe miejsce w prawie i nauce prawa, dostrzegając przy tym, że „nauka prawa zajmuje się przede wszystkim wyjaśnianiem jego roli w procesie stanowienia i stosowania prawa"2. Interes publiczny stanowi pojęcie kluczowe prawa administracyjnego (i publicznego prawa gospodarczego) o wymiarze nie tylko społecznym, ale i prawnym. W tym ostatnim przypadku „materializuje się w postaci klauzuli generalnej interesu publicznego"3.

1 J. Blicharz, Kategoria interesu publicznego jako przedmiot działania administracji publicznej, „Acta Universitatis Wratislaviensis. Przegląd Prawa i Administracji” 2004, t. 40, s. 39.

2 J. Lang, Z rozważań nad pojęciem interesu w prawie administracyjnym, [w:] Przeobrażenia we współczesnym prawie administracyjnym i w nauce administracji, red. A. Błaś, „Acta Universitatis Wratislaviensis. Przegląd Prawa i Administracji” 1997, t. 38, s. 127.

3 A. Żurawik, Klauzula interesu publicznego w prawie gospodarczym krajowym i unijnym, „Europejski Przegląd Sądowy” 2012, nr 12, s. 24. 
W teorii prawa akcentuje się, że klauzula generalna (generalna klauzula odsyłająca) jest konstrukcją normatywną ${ }^{4}$. Niewątpliwie klauzula interesu publicznego ma charakter generalnej klauzuli odsyłającej ${ }^{5}$.

Do najczęściej występujących w tekstach obowiązujących polskich przepisów prawnych generalnych klauzul odsyłających należy zaliczyć odesłania do: zasad współżycia społecznego, społeczno-gospodarczego przeznaczenia prawa, interesu społecznego, interesu publicznego, interesu państwa, zasady sprawiedliwości społecznej, zasad (reguł) słuszności, dobrych obyczajów, dobra dziecka, dobra rodziny ${ }^{6}$.

W literaturze przedmiotu trafnie stwierdza się, że jako konstrukcja międzygałęziowa generalne klauzule odsyłające pojawiają się w prawie administracyjnym.

W samym Kodeksie postępowania administracyjnego znaleźć można kilkanaście odesłań, spośród których najważniejsze znaczenie dla stosowania prawa administracyjnego ma konstrukcja art. 7 k.p.a., odsyłająca organ administracji przy podejmowaniu decyzji do interesu społecznego i słusznego interesu obywateli. Umieszczenie tego przepisu wśród zasad kodeksowych powoduje, że nakaz rozważenia uwzględnienia tych kryteriów odnosi się do każdego aktu zastosowania materialnego i proceduralnego przepisu prawa administracyjnego?

4 Zob. L. Leszczyński, Tworzenie generalnych klauzul odsyłajacych, Lublin 2000, s. 17; idem, Stosowanie generalnych klauzul odsyłających, Kraków 2001, s. 21. Należy tutaj zaznaczyć, że autor ten rozróżnia od siebie generalne klauzule odsyłające od klauzul generalnych rozumianych potocznie, nieodsyłających do kryteriów pozaprawnych - tak też A. Żurawik, Klauzula interesu publicznego..., s. 25. Według L. Leszczyńskiego odesłaniem jest „będące wyraźną konstrukcją prawodawczą (elementem przepisu prawnego) i sformułowane w języku prawnym upoważnienie dla organu stosującego prawo do wyznaczenia zachowania adresata decyzji lub ustalenia podstaw kwalifikacji zachowań adresata normy, na podstawie kryteriów (norm, ocen) wyrażonych (nazwanych) w tekście prawnym, ale nieinkorporowanych (z różnych powodów) do systemu przepisów prawnych" - L. Leszczyński, Tworzenie generalnych klauzul..., s. 17. Autor ten wskazuje wyraźnie, że „Najczęściej spotykana w literaturze nazwa »klauzula generalna« oznacza [...] jeden ze sposobów odsyłania pozaprawnego. Jest zdecydowanie bardziej popularna niż nazwa »klauzula odsyłająca«, »odesłanie« czy jakiś inny termin oznaczający odsyłanie" ibidem, s. 22. L. Leszczyński ostatecznie stwierdza, że generalna klauzula odsyłająca odpowiada wszystkim elementom pojęcia „klauzula generalna” („klauzula odsyłająca”), z tym że kryteria i oceny pozaprawne, do których przez generalne klauzule odsyłające prawodawca się odwołuje, mają charakter ukierunkowany i „systemowy”. Jego zdaniem „Właśnie obecność w konstrukcji klauzuli odesłania do tych kryteriów pozaprawnych jest głównym powodem przyjęcia [...] pełniejszej nazwy (»generalna klauzula odsyłająca«), po to między innymi, aby odróżnić takie użycia terminu »klauzula generalna«, z którym nie wiąże się odesłanie do jakichś kryteriów pozaprawnych” - ibidem, s. 23. Por. M. Wyrzykowski, ,Interes społeczny” jako kategoria proceduralna, „Acta Universitatis Wratislaviensis. Prawo” 1990, nr 1022, s. 344.

5 Tak też: A. Żurawik, Klauzula interesu publicznego..., s. 25.

6 L. Leszczyński, Rozdziat II. Podstawa decyzji stosowania prawa administracyjnego. Ustalenia walidacyjne, [w:] System Prawa Administracyjnego, t. 4: Wyktadnia w prawie administracyjnym, red. R. Hauser, Z. Niewiadomski, A. Wróbel, Warszawa 2012, s. 111.

7 Ibidem, s. 112. 
Poza Kodeksem postępowania administracyjnego ${ }^{8}$ można wskazać pojawianie się generalnych klauzul odsyłających $\mathrm{w}$ materialnym prawie administracyjnym (także w publicznym prawie gospodarczym). Przykładowo można wskazać kryterium właśnie interesu publicznego w ustawie o planowaniu i zagospodarowaniu przestrzennym ${ }^{9}$ (mamy tutaj stworzoną przez ustawodawcę definicję legalną [!] interesu publicznego) czy w ustawie Prawo bankowe ${ }^{10}$ i ustawie o nadzorze nad rynkiem finansowym ${ }^{11}$, gdzie ustawodawca, definiując cele nadzoru bankowego, „określił wartości, których respektowanie wypełnia treść interesu publicznego" ${ }^{12}$. Tytułem innego przykładu można wskazać w materialnym prawie administracyjnym kryterium dobrych obyczajów w ustawie o swobodzie działalności gospodarczej $^{13}$. Ustawa ta posługuje się ponadto, notabene, pojęciem nadrzędnego interesu publicznego (znów mamy tutaj stworzoną przez ustawodawcę definicję legalną [!] nadrzędnego interesu publicznego) ${ }^{14}$. Innym przykładem

8 Ustawa z dnia 14 czerwca 1960 r. - Kodeks postępowania administracyjnego (t.j. Dz.U. z 2013 r., poz. 267 z późn. zm.), dalej jako: k.p.a.

9 Ustawa z dnia 27 marca 2003 r. o planowaniu i zagospodarowaniu przestrzennym (t.j. Dz.U. z 2015 r., poz. 199), dalej jako: u.p.z.p. W art. 2 pkt 4 tej ustawy ustawodawca przez interes publiczny rozumie uogólniony cel dążeń i działań uwzględniających zobiektywizowane potrzeby ogółu społeczeństwa lub lokalnych społeczności, związanych z zagospodarowaniem przestrzennym. Zob. J. Dobkowski, Kategoria interesu publicznego jako przedmiot regulacji ustawy o planowaniu i zagospodarowaniu przestrzennym, [w:] Planowanie strategiczne i przestrzenne, red. R. Biskup, A. Haładyj, „Prawo - Administracja - Kościół” 2006 (nr specjalny), s. 59 i n.

10 Ustawa z dnia 29 sierpnia 1997 r. - Prawo bankowe (t.j. Dz.U. z 2015 r., poz. 128), dalej jako: pr. bank.

11 Ustawa z dnia 21 lipca 2006 r. o nadzorze nad rynkiem finansowym (t.j. Dz.U. z 2012 r., poz. 1149 z późn. zm.), dalej jako: u.n.r.f.

12 Tak: L. Góral, Interes publiczny jako przestanka ingerencji państwa $w$ sferę funkcjonowania rynku bankowego w Polsce $i$ we Francji, „Studia Prawno-Ekonomiczne” 2010, t. 82, s. 65. Zdaniem tego autora wartościami tymi są wskazane w treści art. 133 pr. bank.: bezpieczeństwo środków pieniężnych gromadzonych na rachunkach bankowych; zgodność działalności banków z przepisami ustawy pr. bank., ustawy o Narodowym Banku Polskim, statutem oraz decyzją o wydaniu zezwolenia na utworzenie banku; zgodność działalności prowadzonej przez banki z ustawą o obrocie instrumentami finansowymi (we wskazanym w ustawie pr. bank. zakresie). Por. także: idem, Zintegrowany model publicznoprawnych instytucji ochrony rynku bankowego we Francji i Polsce, Warszawa 2011, s. 62 i n. Zob. też: R. Blicharz, M. Kania, Klauzula interesu publicznego w publicznym prawie gospodarczym, „Przegląd Ustwodawstwa Gospodarczego" 2010, nr 5, s. 12-21.

13 Ustawa z dnia 2 lipca 2004 r. o swobodzie działalności gospodarczej (t.j. Dz.U. z 2013 r., poz. 672 z późn. zm.), dalej jako: u.s.d.g. Art. 17 tej ustawy stanowi, że przedsiębiorca wykonuje działalność gospodarczą na zasadach uczciwej konkurencji i poszanowania dobrych obyczajów oraz słusznych interesów konsumentów.

${ }_{14}$ Zgodnie $\mathrm{z}$ art. 5 pkt 7 u.s.d.g. nadrzędny interes publiczny należy rozumieć tak, jak na to wskazuje art. 2 ust. 1 pkt 7 ustawy z dnia 4 marca 2010 r. o świadczeniu usług na terytorium Rzeczypospolitej Polskiej (Dz.U., nr 47, poz. 278 z późn. zm.), czyli jako wartość podlegającą ochro- 
jest kryterium wartości chrześcijańskich czy dobra społecznego w ustawie o radiofonii i telewizji ${ }^{15}$.

Klauzula interesu publicznego jest związana przede wszystkim z prawem publicznym, głównie z prawem administracyjnym. Ogólnie biorąc, jest ona dyrektywą kierowaną do organów administracji publicznej, które swoje zadania wykonują, a przynajmniej powinny wykonywać, w interesie publicznym. Jak wskazuje A. Żurawik, „Ta kluczowa dla prawa publicznego klauzula była i jest przedmiotem refleksji i bardzo skrajnych ocen - uznaje się ją za kategorię normatywną bądź traktuje jako kategorię polityczną, socjologiczną czy wszelką inną, byle nie normatywną, jako niedającą się prawnie kategoryzować" ${ }^{16}$. Na aprobatę zasługuje konstatacja, że

Związki pomiędzy prawem a życiem społecznym są szerokie, to zaś ma swe odzwierciedlenie w refleksji teoretycznoprawnej innych nauk społecznych. Prawo, w szczególności publiczne, jest wynikiem realizacji określonej polityki, ale również nośnikiem i odzwierciedleniem ważnych społecznie wartości. To zaś wywołuje potrzebę analizy i odkrywania normatywnej zawartości przywołanej klauzuli oraz klauzul podobnych. Do tych ostatnich należą m.in. klauzule „interes społeczny” oraz „interes społecznie uzasadniony”. Co więcej, bardzo często klauzulę interesu publicznego wręcz utożsamia się z klauzulą interesu społecznego i poglądy dotyczące jednej z nich automatycznie odnosi do drugiej. Na tej samej zasadzie czasem traktuje się tak samo klauzulę interesu społecznego oraz interesu społecznie uzasadnionego ${ }^{17}$.

Jeśli wymienione klauzule traktować normatywnie, a nie jako przykład „pustosłowia" ustawodawcy, to próba dookreślenia ich treści jest oczywista. M. Wyrzykowski (który jako korelat klauzuli interesu społecznego traktował klauzulę interesu publicznego) stwierdzit:

Względny charakter treści interesu publicznego nie oznacza jej dowolności. Dlatego wszelkie próby, nawet te, które zmierzają do określenia minimum pewności znaczenia pojęcia, muszą być powitane z uznaniem. Są to bowiem próby określenia nienaruszalnych, w danych warunkach społecznych i ustrojowych, granic interesu publicznego jako dobra wspólnego ${ }^{18}$.

nie, w szczególności porządek publiczny, bezpieczeństwo publiczne, zdrowie publiczne, utrzymanie równowagi finansowej systemu zabezpieczenia społecznego, ochrona konsumentów, usługobiorców i pracowników, uczciwość w transakcjach handlowych, zwalczanie nadużyć, ochrona środowiska naturalnego i miejskiego, zdrowie zwierząt, własność intelektualna, cele polityki społecznej i kulturalnej oraz ochrona narodowego dziedzictwa historycznego i artystycznego.

15 Art. 18 i 21 ustawy z dnia 29 grudnia 1992 r. o radiofonii i telewizji (t.j. Dz.U. z 2011 r., nr 43, poz. 226 z późn. zm.).

16 A. Żurawik, ,Interes publiczny”, ,,interes społeczny” $i$,,interes społecznie uzasadniony”. Próba dookreślenia pojęć, ,Ruch Prawniczy, Ekonomiczny i Socjologiczny” 2013, nr 2, s. 57.

17 Ibidem, s. 57-58.

18 M. Wyrzykowski, Pojęcie interesu społecznego w prawie administracyjnym, Warszawa 1986, s. 47, podaję za: A. Żurawik, „Interes publiczny”..., s. 58. 
Kategoria interesu publicznego była do tej pory przedmiotem dużego zainteresowania prawników, politologów, filozofów, ekonomistów czy socjologów. Wyraźnie zauważalny jest brak konsensusu co do tego, czym jest interes publiczny ${ }^{19}$. Pojawiły się różne koncepcje, gdzie interes ten próbowano analizować z różnych punktów widzenia przy jednoczesnym stwierdzeniu braku możliwości stworzenia jego poprawnej definicji ${ }^{20}$, takiej, która obowiązywałaby w każdych warunkach i w każdym czasie.

Koncepcje interesu publicznego są klasyfikowane na trzy, a właściwie cztery typy. Jedną z koncepcji jest przyjęcie związania interesu publicznego z wartościami (koncepcje aksjologiczne). Zgodnie z nią

[...] pojęcie interesu publicznego stanowi normatywną wskazówkę powinnościową wyznaczającą zakres i treść wartości uznawanych przez daną społeczność za zasługujące na ochronę bez względu na indywidualne przekonania jednostek. Jest też granicą dopuszczalnej ingerencji władzy publicznej w stosunki społeczne i gospodarcze oraz w wolności obywateli, a z punktu widzenia obywateli stanowi granicę swobody działalności jednostek ${ }^{21}$.

Druga z koncepcji interesu publicznego odnosi ten interes do celów (koncepcje prakseologiczne - rzadkie w czystej postaci). W ramach tej koncepcji podstawą dookreślania interesu „może być kategoria celu, gdy $x$ jest interesem podmiotu $A$ ze względu na cel $y$, stojący przed podmiotem"22. Trzecia koncepcja wiąże interes publiczny z potrzebami; podstawą interesu

[...] mogą być potrzeby lub zbiór potrzeb $-x$ będzie tu interesem $A$ ze względu na potrzebę $y$. Cześć autorów [...] wręcz utożsamia interes z potrzebą, twierdząc np., że interesy to społecznie zdeterminowane potrzeby, a część je wyraźnie oddziela, z tym że sama potrzeba może być przez nich rozumiana dwojako: albo subiektywistycznie (jako wyrażone życzenie, świadoma skłonność, odczuwane pragnienie), albo obiektywnie (gdy potrzeba występująca w podstawie interesu jest ujmowana niezależnie od wyobrażeń i subiektywnych przekonań poszczególnych osób) ${ }^{23}$.

19 Interesujące są w tym zakresie uwagi A. Żurawika: „Pendleton Herring twierdził, że koncept interesu publicznego jest dla biurokracji tym, czym właściwa procedura prawna dla sądownictwa. W podobnym tonie wypowiadali się Daniel Bell i Irving Kristoll. Pisali bowiem: »Naprawdę wierzymy, że termin ten [...] nie zostanie porzucony. Nie istniało jeszcze społeczeństwo, które by [...] do pewnego stopnia nie kierowało się zasadami tego ideału«. Problematyka ta jest jednak polem bardzo kontrowersyjnych dociekań. Virginia Held uważała, że koncept interesu publicznego, ukształtowany w dużej mierze przez takie elementy, jak brutalna siła, polityczna konieczność czy wątpliwa motywacja, może nawet niekiedy potrzebować narzuconego z góry porządku. Wyraźnie jest tu też zauważalny brak konsensusu odnoszący się do stwierdzenia, czym jest ów interes publiczny. Traktowany jest więc on niekiedy jako termin pusty, zwodniczy, a nawet bezużyteczny" - idem, Klauzula interesu publicznego..., s. 25.

20 Ibidem, s. 26.

${ }^{21}$ Ibidem.

${ }^{22}$ Idem, ,Interes publiczny”..., s. 59.

23 Ibidem. 
Spotykane są też koncepcje mieszane interesu publicznego (koncepcje hybrydalne - często spotykane). Należy tu wskazać między innymi koncepcję Eugeniusza Modlińskiego, który odnosił interes publiczny do potrzeb i celów. Głosił on nadrzędność interesu publicznego w stosunku do indywidualnych interesów i potrzeb jednostki ${ }^{24}$. Koncepcję hybrydalną przedstawił również M. Wyrzykowski, który

Pisząc o interesie społecznym (publicznym), nawiązywał do wartości oraz do celów. Zwracał uwagę na akcentowany w teorii prawa i teorii polityki związek między systemem wartości a określaną przez te wartości treścią interesu publicznego. Interes publiczny rozpatrywał też z punktu widzenia celów, głównie celów państwa. Zaznaczał złożony i względny charakter treści interesu społecznego (publicznego), zmienny w czasie i przestrzeni, choć niemogący oznaczać mimo to dowolności w traktowaniu omawianej klauzuli25 .

Sam ustawodawca nie jest tutaj zdecydowany, jaką koncepcję wybrać, opierając się na różnych spośród wskazanych. Na przykład w powołanej wcześniej ustawie o planowaniu i zagospodarowaniu przestrzennym odnosi się on i do celów, i do potrzeb (koncepcja hybrydalna), natomiast w ustawie o świadczeniu usług na terytorium RP (do której odwołuje się u.s.d.g.) ustawodawca wybrał koncepcję aksjologiczną ${ }^{26}$.

Jeżeli chodzi o problem zastosowania kryteriów otwartych w prawie administracyjnym, w tym klauzuli interesu publicznego oraz ich interpretację, to w literaturze przedmiotu zwraca się uwagę na to, że

Udział kryteriów otwartych w procesie rekonstrukcji normatywnej podstawy decyzji stosowania prawa administracyjnego oznacza przede wszystkim wyjście poza argumenty bezpośrednio związane z przepisami prawnymi oraz w tych przepisach określone. W przypadku kryteriów otwartych wyjście to nie oznacza samodzielności podmiotu stosującego prawo (interpretatora) w kreowaniu tych kryteriów. To ostatnie zależy bowiem od prawodawczego (normatywnego) sformułowania generalnych klauzul odsyłających, będących formalnymi nośnikami tych kryteriów. Samodzielność interpretatora oznacza natomiast swobodę w nadaniu klauzuli odpowiedniej treści, w zadecydowaniu o posłużeniu się tymi kryteriami przy rekonstrukcji (zwłaszcza dotyczy to sytuacji zawarcia kryterium otwartego w klauzuli zawartej w przepisach ogólnych) oraz w określeniu jej roli rekonstrukcyjnej ${ }^{27}$.

W kontekście roli generalnych klauzul odsyłających, w tym klauzuli interesu publicznego w gałęzi prawa administracyjnego, w jego stosowaniu i wykładni, zasadne jest przytoczenie trafnej w tym zakresie uwagi L. Leszczyńskiego.

24 E. Modliński, Pojęcie interesu publicznego w prawie administracyjnym, Warszawa 1932, s. 13, podaję za: A. Żurawik, Klauzula interesu publicznego..., s. 26.

25 A. Żurawik, Klauzula interesu publicznego..., s. 26.

26 Tak też: ibidem.

27 L. Leszczyński, Rozdział VII. Interpretacyjna rola kryteriów otwartych i innych decyzji stosowania prawa, [w:] System Prawa Administracyjnego..., s. 307. 


\section{Stwierdza on, po pierwsze,}

[...] ogólnie rzadsze odwoływanie się do kryteriów pozaprawnych przez organy administracyjne. Nie można wprawdzie stwierdzić z całą pewnością, że organy administracyjne rzadziej biorą pod uwagę możliwość zastosowania klauzuli odsyłającej (kierują swoje rozumowania na wykorzystanie argumentów aksjologicznych), ale na pewno odesłania rzadziej pojawiają się w samych decyzjach administracyjnych (ich uzasadnieniach). Nie można wykluczyć, że rozumowanie takie postrzegane jest jako mniej pewne (mniej zobiektywizowane) i przez to bardziej narażone na zanegowanie i korektę, nie tylko co do treści, ale także co do sposobu przeprowadzenia, przez instancję wyższą lub sąd administracyjny. Niezbędne jest zatem mocne przekonanie (które może płynąć z różnych przyczyn) o celowości takiego otwarcia aksjologii w procesie decyzyjnym. Po drugie, jeśli odesłanie pojawia się już jako element źródła rekonstrukcji, odgrywa zwykle istotną rolę w budowaniu treści decyzji. Nie jest jedynie „douzasadnieniem” rozwiązania przyjętego w przepisie. Rzadsze powoływanie oznacza zatem mocniejszą - w przypadku powołania - ich rolę. Dotyczy to zwłaszcza budowania treści decyzji. Po trzecie, najczęściej powoływane są kryteria z art. 7 k.p.a., co nie może oczywiście dziwić, m.in. z racji ogólności odesłania nakazującego rozważenie zastosowania i umożliwiającego wykorzystanie tych kryteriów w każdym procesie decyzyjnym, ze szczególnym uwzględnieniem decyzji uznaniowych. Po czwarte, brak jest zwykle w administracyjnych procesach decyzyjnych bardziej złożonych argumentacji dotyczących korzystania z kryteriów pozaprawnych (np. dotworzeń odesłań, zapożyczeń odesłań per analogiam, łącznego powoływania różnych kryteriów, prób rozstrzygania kolizji między kryteriami). Wskazuje to na ostrożność organów administracyjnych, która wynika, jak się wydaje, z postrzegania mniejszej pewności rozumowań opartych na tych kryteriach, wpływającej na potencjalny wynik kontroli decyzyjnej i sądowej. Po piąte, odwoływanie się do klauzul odsyłających w administracyjnym typie stosowania prawa traktowane jest jako element swoistego uznania administracyjnego (sensu largo), nawet jeśli w istocie nie jest to uznaniowy typ decydowania. Odpowiada to w pewnym sensie istocie orzecznictwa słusznościowego na gruncie prawa prywatnego. Niewątpliwie wynika też z pozycji i roli decyzyjnej regulacji art. 7 k.p.a., która traktowana jest (zwłaszcza w orzecznictwie sądów administracyjnych ${ }^{28}$ ) jako ogólna wskazówka korzystania z konstrukcji uznania. Organy administracyjne, jak się wydaje, skłonne są traktować klauzule odsyłające jako nie tyle rodzaj upoważnienia do podejmowania decyzji uznaniowych, ile jako wskazanie aksjologicznych aspektów („,ograniczników”) treści decyzji uznaniowej. Po szóste, posługiwanie się kryteriami otwartymi przez organy administracji zależy - jak żaden inny rodzaj zastosowania odesłań - od typu systemu politycznego, który może wymagać „celowego" stosowania prawa albo stosowania uwzględniającego aksjologię ideologiczną i polityczną, jak to ma miejsce w systemach autokratycznych (i wówczas wskazany wyżej element niepewności co do wykorzystania kryterium zastąpiony jest wolą i obowiązkiem uwzględniania tej aksjologii), albo stosowania pragmatycznego, uwzględniającego obok elementów kierowania rzeczywistością polityczną odwoływanie się do aksjologii społecznej (co ma miejsce w systemach demokratycznych). Relatywizacja powyższa powinna być ponadto uzupełniona o cechy, powiązanego zwykle z systemem politycznym, typu systemu gospodarczego (co jest istotne zwłaszcza dla stosowania administracyjnego prawa gospodarczego) czy głębokości zmiany społecznej (co może dodatkowo zwiększać zakres wykorzystania aksjologii, ale także zmieniać sposób jej uwzględniania) ${ }^{29}$.

28 Zob. np. wyrok WSA w Warszawie z dnia 23 września 2005 r., IV SA/Wa 671/05, CBOSA; wyrok NSA z dnia 17 lipca 2009 r., II FSK 2137/08, Legalis; wyrok WSA w Warszawie z dnia 2 czerwca 2008 r., II SA/Wa 2125/07, Legalis - podaję za: L. Leszczyński, Rozdział II. Podstawa decyzji..., s. 116; idem, Rozdziat VII. Interpretacyjna rola kryteriów..., s. 334.

29 Idem, Rozdziat II. Podstawa decyzji..., s. 116-117. 
Wykładnia samej generalnej klauzuli odsyłającej, która odsyła do kryterium otwartego, przebiega analogicznie oraz ,przy użyciu tych samych reguł rekonstrukcji, które występują przy wykładni »całych « przepisów prawnych"30, tak jak ma to miejsce przy ustaleniu znaczenia każdego wyrażenia normatywnego. Zastosowanie będą więc miały w odniesieniu do tej konstrukcji reguły językowe i systemowe oraz reguły celowościowe i funkcjonalne. Zauważyć przy tym należy, że

Niezależnie od sposobu sformułowania klauzuli odsyłającej warstwa semantyczna odnosząca się do ustalenia znaczenia całego wyrażenia odgrywa daleko mniejszą rolę, niż ma to miejsce w przypadku typowych (jurydycznych) i sformalizowanych wyrażeń języka prawnego. Nie chodzi tu bowiem o semantyczną klaryfikację tych wyrażeń, lecz o zakreślenie pola aksjologicznego, w którym wartości identyfikowane w procesie wykładni takiego pojęcia się mieszczą. [...] Mówiąc najogólniej, dla ustalenia treści kryterium klauzuli odsyłającej nie jest najistotniejsze ustalenie znaczenia językowego pojęcia „interes” w odesłaniach do interesu społecznego czy słusznego interesu obywateli, w kontekście np. przesądzenia, czy chodzi tu o interes w znaczeniu socjologicznym, czy o jakieś dobro lub reguły (zasady). Dla treści odesłania najważniejsze jest określenie zakresu aksjologicznego, jaki może się w takim zwrocie mieścić. Istotna w tym kontekście jest więc identyfikacja treści danego terminu z określonym typem wartości, w ramach którego może mieć miejsce poszukiwanie odniesień politycznych czy gospodarczych poszczególnych odesłań. [...] Elementem tych rozumowań w stosowaniu prawa administracyjnego jest identyfikacja $\mathrm{z}$ interesem ogólnym (publicznym), który stanowi „emanację” prawa administracyjnego i który może być jedynie korygowany przez określone rozumienie interesu indywidualnego. Ma to miejsce w różnej skali, w różnych subgałęziach i w zależności od wielu czynników zmienności. Stąd decydującą rolę w wykładni generalnych klauzul odsyłających odgrywają pozajęzykowe reguły wykładni, bliżej określające aksjologiczną lub funkcjonalną treść danego kryterium otwartego ${ }^{31}$.

Zdaniem L. Leszczyńskiego można sformułować kilka podstawowych wniosków, wskazówek odnośnie do wykładni generalnych klauzul odsyłających (w tym klauzuli interesu publicznego). Przede wszystkim zwraca on uwagę na to, że

Zasadniczy i decydujący charakter argumentacji aksjologicznej w interpretacji klauzuli odsyłającej i ustalaniu treści kryterium powinien być wykazany starannie w uzasadnieniu decyzji administracyjnej. Sposób ustalania treści kryteriów pozaprawnych wiąże się, po pierwsze, z odejściem od dominacji rozważań językowych odnośnie do zwrotu wyrażającego takie kryterium, po drugie, z pomocniczym odwołaniem się do relacji systemowo-strukturalnych związanych z miejscem sformułowania tego zwrotu zarówno w systematyce aktu normatywnego, jak i w rodzaju aktu i gałęzi prawa, oraz, po trzecie, z dominującą rolą ustaleń aksjologii pozasystemowej (pozaprawnej), z którą wiązana jest treść odesłania i która pojawia się nie jako argumentacja weryfikacyjno-korekcyjna, lecz jako argumentacja zasadnicza wykładni. Dominacja tych ustaleń powinna być odzwierciedlana w uzasadnieniu decyzji administracyjnej w sensie niewywołującego wątpliwości wykazania samych wartości, sposobu dojścia do ustalonych wartości oraz podstaw tego ustalenia. Ważenie aksjologii ogólnej (interes społeczny czy publiczny) z aksjologią jednostkową (interes obywateli, strony itp.) powinno stać się trwałym elementem praktyki decyzyjnej, powinno być starannie przeprowadzane i uzasadniane w decyzji administracyjnej. W administracyjnym stosowaniu prawa decydujące zna-

30 Idem, Rozdziat VII. Interpretacyjna rola kryteriów..., s. 308.

31 Ibidem, s. 309-310. 
czenie ma związana z ustalaniem różnic nazwanych kryteriów pozasystemowych relacja między perspektywą ogólną a perspektywą jednostkową treści danego kryterium (danej aksjologii). Najpełniej jest to widoczne w przypadku relacji między kryterium interesu publicznego i interesu obywatela (strony) jako interesu jednostkowego. Naturalna dominacja interesu społecznego (publicznego) w stosowaniu prawa administracyjnego powoduje potrzebę wykazywania szczególnej ostrożności w preferowaniu tego kryterium, co sprowadza się do stwierdzania potrzeby odpowiedniego ważenia argumentów stojących za oboma typami interesów (czy szerzej - perspektyw ujmowania wartości). Ustalanie aksjologii pozaprawnej powinno się odnosić do rzetelnego odczytywania aksjologii społecznej (w obu wskazanych perspektywach) w powiązaniu z okolicznościami konkretnego stanu faktycznego i nie prowadzić, także przy koniecznych niekiedy powiązaniach z aksjologią polityczną (w postaci uwzględniania polityki stosowania prawa administracyjnego), do instrumentalizacji tej aksjologii. Unikanie naturalnej, w przypadku administracyjnego stosowania prawa, skłonności do upolityczniania, w sensie związania wyników wykładni tych odesłań z aksjologią wskazaną w ramach polityki stosowania prawa, powinno się ograniczać do ustalania aksjologii niesprzecznej z tą polityką, a nie z politycznym uzasadnianiem każdej treści odesłania. Musiałoby to bowiem prowadzić do praktyk bezkrytycznego preferowania w stosowaniu prawa administracyjnego aksjologii ogólnospołecznej (publicznej), przy wiązaniu tych ustaleń z aktualną linią polityki. Praktyka ta może być realizowana przez unikanie ogólności w budowaniu treści kryteriów oraz przez wiązanie ich treści z właściwościami ustalonego stanu faktycznego („faktualny kontekst wartościowania”). Problem polega bowiem na tym, że aksjologia polityczna jest aksjologią „mocną”, popartą instytucjonalnie i sformalizowaną (w programach politycznych), stąd nie tylko łatwo identyfikowalną, ale także, biorąc pod uwagę cechy administracyjnego typu stosowania prawa, naturalnie „wchodzącą" do praktyki decydowania. Konkretność ustaleń aksjologicznych, także w postaci szczegółowo zidentyfikowanych i wykazanych w uzasadnieniu związków z elementami stanu faktycznego, może przynajmniej częściowo równoważyć tę ogólną właściwość. Ustalanie aksjologii pozaprawnej powinno się mieścić w ramach aksjologicznych wyznaczonych przez zasady prawa. Wiązanie treści kryteriów pozaprawnych z zasadami prawa (aksjologią wewnątrzprawną) jest drugą stroną gwarancji nieupolityczniania i unikania nadmiernego uogólniania treści ustalanych kryteriów pozaprawnych. Stanowi to element podstawowej zgodności obu aksjologii, w kontekście unikania $\mathrm{w}$ procesach stosowania prawa zasadniczej sprzeczności wartościowania pozaprawnego z aksjologią prawną, co mogłoby doprowadzić do dysfunkcjonalności porządku prawnoadministracyjnego. Mając na uwadze wolę ustalenia aksjologii pozaprawnej i włączenia jej w proces decydowania, wynikający z samej praktyki formułowania klauzul, należy stwierdzić, że praktyka administracyjna powinna tym bardziej unikać wykorzystania wszystkich możliwości, jakie z otwartego charakteru tych kryteriów płyną, także w kontekście ustalania treści tych kryteriów. Stąd konieczny związek z zasadami prawa wyraźnie sformułowanymi (także konstytucyjnymi czy ponadnarodowymi), ale także zasadami kulturowymi czy zasadami „brzegowymi”, występującymi na pograniczu metaklauzul i wartości obejmujących przynajmniej częściowo także aksjologię pozasystemową (np. zasad z art. 2 Konstytucji RP). Zgodność aksjologii pozaprawnej z aksjologią zasad prawa wpływa także w sposób wyraźny na jednolitość w ustalaniu treści poszczególnych odesłań. Realizuje w ten sposób jeden z najważniejszych postulatów stosowania i wykładni prawa, także administracyjnego, aktualny zwłaszcza w sytuacji konstrukcji co do istoty otwierającej aksjologię, a więc potencjalnie osłabiającej jednolitość obu procesów. W pewnym zakresie skutek taki może być osiągnięty w sytuacji zgodności wyborów aksjologicznych klauzul szczegółowych rzadziej występujących łącznie z aksjologią wyznaczoną przez klauzule zasadnicze dla prawa administracyjnego (meta-klauzule), do jakich niewątpliwie należy zaliczyć interes społeczny (publiczny) odpowiednio ważony interesem obywatela. Kontrola sądowoadministracyjna nie powinna całkowicie unikać kontroli praktyki ustalania treści kryteriów pozaprawnych przez organ administracji publicznej, mimo potencjalnych trudności jej uzasadnienia w związku z zasadą kontroli legalności decyzji administracyjnej. Ograniczoność kontroli sądowej wiąże się przede wszystkim z ostrożną ingerencją w ustalanie treści 
danego kryterium, ale nie powinna się wiązać z unikaniem oceny sposobu ustalenia tej treści, związku ustalonych wartości z modelową relacją między interesem społecznym a jednostkowym, oceny ważenia obu interesów, zakresu powiązania ustalonych wartości z elementami stanu faktycznego czy zakresu powiązania aksjologii pozaprawnej z aksjologią ogólnosystemowych i administracyjnoprawnych zasad prawa. Kontrola ta powinna zwracać szczególną uwagę na sposób uzasadnienia ustalania treści takiego kryterium ${ }^{32}$.

Na specyficzny związek relacji interes jednostki - interes publiczny (społeczny) z zasadami prawa zwraca uwagę M. Zdyb. Zauważa on, że „pojęcie interesu publicznego nabiera pełnej treści dopiero przez zestawienie z prawem poszczególnej jednostki, jako namiastki wszelkiej społeczności”33. Jego zdaniem ewentualną dysharmonię, a nawet konflikt między tymi interesami, należy rozwiązać przede wszystkim z zastosowaniem zasad postępowania administracyjnego ${ }^{34}$. Autor ten zdecydowanie stwierdza, że ,wszelkie relacje w stosunkach publicznoprawnych powinny być kształtowane w ten sposób, aby uwzględniały kwintesencję interesów prawnych ucieleśnionych w godności człowieka oraz interes publiczny, a zwłaszcza jego najpełniejsze wcielenie, tj. dobro wspólne" ${ }^{35}$. Ponadto W.J. Wołpiuk twierdzi wyraźnie, że realizacja interesu publicznego (jako wartości konstytucyjnej) nie stanowi legitymacji do naruszania innych wartości i zasad ${ }^{36}$.

W literaturze przedmiotu dostrzega się wielofunkcyjność kategorii interesu społecznego (publicznego). Podkreśla się przy tym, że w ogóle generalne klauzule odsyłające mają na celu uelastycznienie prawa ${ }^{37}$, a prawo to powinno służyć nie tylko interesowi publicznemu (społecznemu) czy państwowemu, regionalnemu czy lokalnemu, ale również przyczyniać się do realizacji interesu jednostki. Poza tym

Interes jako kategoria aksjologiczna jest o tyle charakterystyczny dla stosowania prawa administracyjnego, o ile najpełniej wyraża organizacyjną funkcję tego prawa. Wiąże się to z realizacją w drodze stosowania tego prawa określonych interesów ogólnych czy grupowych oraz indywidualnych. Tym samym aksjologia pozasystemowa związana ze stosowaniem tego prawa łączy się z wartościami politycznymi, wynikającymi z realizacji przez organy administracji określonej polityki państwa. Relacja między tymi interesami i wartościami z nimi identyfikowanymi

32 Ibidem, s. 323-326. Zob. także: idem, Kategoria interesu $w$ stosowaniu prawa administracyjnego. Przyktad art. 7 KPA, [w:] Pojęcie interesu w naukach prawnych, prawie stanowionym i orzecznictwie sądowym Polski i Ukrainy, red. A. Korybski, M.W. Kostyckij, L. Leszczyński, Lublin 2006, passim.

33 M. Zdyb, Interes jednostki a interes publiczny (społeczny). Konflikt interesów, „Annales UMCS. Sectio G” 1993, Vol. 40, s. 307. Zob. też: idem, Interes publiczny w orzecznictwie Trybunału Konstytucyjnego, [w:] Pojęcie interesu w naukach prawnych..., s. 205 i n.; idem, Prawny interes jednostki w sferze materialnego prawa administracyjnego, Lublin 1991.

${ }_{34}$ Idem, Interes jednostki a interes publiczny..., s. 307.

35 Idem, Interes publiczny $w$ orzecznictwie..., s. 205.

36 W.J. Wołpiuk, Dobro wspólne a interes publiczny, „Zeszyty Naukowe Wyższej Szkoły Informatyki, Zarządzania i Administracji w Warszawie" 2006, z. 1, s. 22.

37 A. Żurawik, Klauzula interesu publicznego..., s. 30. 
w drodze wykładni treści kryteriów jest jednocześnie elementem przesądzającym o wielu cechach szczegółowych regulacji administracyjnoprawnej (np. o zakresie interwencjonizmu państwowego, o autokratycznym bądź demokratycznym jego charakterze, o relacji między aksjologią moralną i polityczną czy o skłonności do uwzględniania interesów indywidualnych) ${ }^{38}$.

Dla określenia istoty pojęcia interesu publicznego ważne znaczenie miało orzecznictwo Trybunału Konstytucyjnego, zwłaszcza wtedy, gdy odnosiło się do zagadnienia ograniczenia praw i wolności konstytucyjnie chronionych. Ustrojodawca dopuszcza możliwość takiego ograniczenia, ale jednocześnie wskazuje - wprawdzie w sposób bardzo ogólny i niedookreślony, ale jednak - granice ingerencji państwa w ich treść przy odniesieniu się do interesu publicznego lub jego konkretnych kategorii. Przykładowo w wyroku z dnia 8 kwietnia 1998 r. przyjmuje, że

[...] działalność gospodarcza, ze względu na jej charakter, a zwłaszcza na bliski związek zarówno z interesami innych osób, jak i interesem publicznym, może podlegać różnego rodzaju ograniczeniom w stopniu większym niż prawa i wolności o charakterze osobistym bądź politycznym. Istnieje w szczególności legitymowany interes państwa w stworzeniu takich ram prawnych obrotu gospodarczego, które pozwolą zminimalizować niekorzystne skutki mechanizmów wolnorynkowych, jeżeli skutki te ujawniają się w sferze, która nie może pozostać obojętna dla państwa ze względu na ochronę powszechnie uznawanych wartości [...]. Istnieje w szczególności legitymowany interes państwa w stworzeniu takich ram prawnych obrotu gospodarczego, które pozwolą zminimalizować niekorzystne skutki mechanizmów wolnorynkowych, jeżeli skutki te ujawniają się w sferze, która nie może pozostać obojętna dla państwa ze względu na ochronę powszechnie uznawanych wartości ${ }^{39}$.

Niewątpliwie, dla określenia istoty interesu publicznego, ważne znaczenie miały także wyroki Trybunału dotyczące ograniczenia wolności gospodarczej ze względu na interes (ważny interes) publiczny w kontekście prawa do sądu. Mając to na uwadze, Trybunał Konstytucyjny w wyroku z dnia 14 czerwca 1999 r. stwierdził:

Wzorce konstytucyjne, wskazane we wniosku, skonfrontowane być muszą z interesem publicznym, dla ochrony którego wprowadzono ograniczenia w korzystaniu z prawa do sądu. W przedmiotowej sprawie [jak trafnie zauważa Prokurator Generalny RP - dop. M. Z.] chodzi nie tylko o te dobra, o których mowa w art. 31 ust. 3 Konstytucji, lecz także o konflikt pomiędzy wolnością prowadzenia działalności gospodarczej, która może być ograniczana tylko ze względu na ważny interes publiczny (art. 22 Konstytucji), a prawem każdego do sądu (art. 45 Konstytucji). Zgodzić się należy w pełni [podkreśla TK - dop. M. Z.] ze stanowiskiem Rzecznika Praw Obywatelskich oraz Prokuratora Generalnego, iż ważny interes publiczny, o którym mowa w art. 22 Konstytucji, nie może być interpretowany rozszerzająco i prowadzić do ograniczenia innego odrębnego prawa - prawa do sądu ${ }^{40}$.

38 L. Leszczyński, Rozdziat VII. Interpretacyjna rola kryteriów..., s. 315-316.

39 Wyrok TK z dnia 8 kwietnia 1998 r., sygn. K 10/97, OTK ZU 1998/55/363.

40 Wyrok TK z dnia 14 czerwca 1999 r., sygn. K 11/09; OTK ZU 1999/5/97. 
Nie zmienia to tezy, że ważny interes publiczny może być podstawą do dokonania różnego rodzaju ograniczeń uzasadnionych ważnym interesem publicznym (np. ze względu na zagrożenie dla życia, zdrowia, porządku publicznego itd.), a także ze względu na potrzebę ochrony moralności publicznej, ochrony środowiska czy konieczność ochrony innych praw i wolności konstytucyjnie chronionych. Trzeba jednak mieć na uwadze, iż

[...] „konieczność”, o której mowa w art. 31 ust. 3 [a także w art. 22 Konstytucji RP - dop. M. Z.] mieści w sobie postulat niezbędności, przydatności i proporcjonalności. Zgodnie z ukształtowanym orzecznictwem Trybunału Konstytucyjnego, dla oceny, czy doszło do naruszenia zasady proporcjonalności (zakazu nadmiernej ingerencji) niezbędne jest udzielenie odpowiedzi na trzy pytania: 1) czy wprowadzona regulacja ustawodawcza jest w stanie doprowadzić do zamierzonych przez nią skutków; 2) czy regulacja ta jest niezbędna dla ochrony interesu publicznego, z którym jest powiązana; 3) czy efekty wprowadzanej regulacji pozostają w proporcji do ciężarów nakładanych przez nią na obywatela. Wyczerpującej odpowiedzi na tak sformułowane pytania udzielił Trybunał Konstytucyjny w uzasadnieniu wyroku ${ }^{41}$.

$\mathrm{Na}$ zasadnicze problemy związane $\mathrm{z}$ określeniem istoty takich klauzul generalnych, jak interes publiczny, M. Zdyb wielokrotnie zwracał uwagę w szeregu wcześniejszych publikacji ${ }^{42}$.

41 Wyrok TK z dnia 12 stycznia 1999 r., sygn. P. 2/98, OTK ZU 1999/1/1.

42 Niezależnie od wyżej wymienionej monografii M. Zdyba pt. Prawny interes jednostki w sferze materialnego prawa administracyjnego. Studium teoretyczno-prawne, zagadnienia te były przedmiotem jego rozważań w innych publikacjach. Zob. między innymi: M. Zdyb, Ochrona interesu indywidualnego $w$ sferze prawa administracyjnego. Jednostka w systemie normatywnych uwarunkowań państwa prawnego, „Folia Societatis Scientarum Lublinensis” 1990, Vol. 32; idem, Interes jednostki a interes publiczny...; idem, Drogi i bezdroża państwa prawnego, [w:] Konstytucja, ustrój, system finansowy państwa. Księga pamiątkowa ku czci Prof. Natalii Gajl, Warszawa 1999, s. 197-235; idem, Państwo prawa w perspektywie zaszłości historycznych oraz dokonujących się zmian, [w:] Współczesne problemy prawa publicznego, red. S. Fundowicz, Lublin 1999, s. 17-49; M. Zdyb, J. Stelmasiak, J. Szreniawski, Zasada proporcjonalności w świetle Konstytucji RP, [w:] Podmioty administracji publicznej i prawne formy ich działania. Studia i materiaty z konferencji jubileuszowej Profesora Eugeniusza Ochendowskiego, Toruń 2005, s. 469-483; M. Zdyb, Dobro wspólne w perspektywie art. 1 Konstytucji RP, [w:] Trybunat Konstytucyjny. Księga XV-lecia, Warszawa 2001, s. 190-205; idem, Wspólnotowe i polskie publiczne prawo gospodarcze, t. 1: Wolność i reglamentacja działalności gospodarczej. Handel zagraniczny, Warszawa 2008; idem, Zasady ogólne kodeksu postępowania administracyjnego jako fundament kształtowania wspótczesnego tadu konstytucyjnego, [w:] Kodyfikacja postępowania administracyjnego na 50-lecie K.P.A., red. J. Niczyporuk, Lublin 2010, s. 945-959; idem, Komentarz do art. 3 ustawy z dnia 16 kwietnia 1993 r. o zwalczaniu nieuczciwej konkurencji, [w:] Ustawa o zwalczaniu nieuczciwej konkurencji. Komentarz, red. M. Zdyb, M. Sieradzka, Warszawa 2011, s. 78-131; idem, Administracyjnoprawne ograniczenia praw rzeczowych, [w:] System Prawa Administracyjnego, t. 7: Materialne prawo administracyjne, red. R. Hauser, Z. Niewiadomski, A. Wróbel, Warszawa 2012, s. 549-573; M. Zdyb, M. Sieradzka, Interpretacja treści klauzuli generalnej pojęcia czynu nieuczciwej konkurencji w świetle innych przepisów ustawy o zwalczaniu nieuczciwej konkurencji, „Przegląd Prawa Handlowego” 2011, nr 12, s. 19-30; M. Zdyb, M. Sieradzka, Ustawa o swobodzie dziatalności gospodarczej. Komentarz, Warszawa 2013, s. 139-153. 
Zwrócić należy też uwagę na to, że prawodawca nierzadko posługuje się pojęciem „ważny interes publiczny” w znaczeniu, które wskazuje na to, że w tego typu sytuacjach chodzi o interes państwa ${ }^{43}$. W rzeczywistości może to oznaczać interesy państwa dedukowane przez konkretny organ administracji, natomiast w dalszej perspektywie przez osobę fizyczną (będącą) działającą jako organ administracji, a skoro organy administracji nie mają własnych interesów, to odczytywane przez nie treści traktuje się jako interes publiczny. Problem pojawia się wtedy, gdy administracja wyobcowuje się i zaczyna żyć własnym życiem, gdy aparat administracyjny w takich sytuacjach zacznie być utożsamiany z państwem. Przy takim podejściu - co wielokrotnie podkreślał M. Zdyb - słynna heglowska idea państwa jako nosiciela ogólności może przyjąć złowrogi sens (czego doświadczyliśmy w okresach triumfów europejskich totalitaryzmów) i prowadzić do wynaturzenia interesu publicznego ${ }^{44}$.

Istotne znaczenie dla określenia istoty pojęć niedookreślonych, w tym klauzuli interesu publicznego, ma uwzględnienie kilku dość istotnych uwag. Otóż pojęcie interesu publicznego nie jest pojęciem, którego treść mogłaby być zapełniana w sposób dowolny. Niedookreśloność nie oznacza bowiem możliwości dowolnego zapełniania treści klauzul generalnych przez organy państwa stosujące przepisy prawne posługujące się klauzulami generalnymi (pojęciami o dużym stopniu niedookreśloności). Pojęcia te mają bowiem swoją treść, chociaż często ukrytą. Nie oznacza to jednak, że właściwy organ przez użycie tego pojęcia otrzymał duży zakres władzy dyskrecjonalnej. W sytuacji, gdy ustawodawca posługuje się pojęciami nieostrymi i klauzulami generalnymi, takimi jak interes publiczny, organ administracji czy sąd stosujący prawo, nie otrzymuje prawa do swobodnego określania ich treści. Można natomiast przyjąć, że został przez to na niego nałożony obowiązek odszukania optymalnych treści wyrażających istotę interesu publicznego.

Niewątpliwie należy przyjąć, że w każdym pojęciu niedookreślonym jest zawarte odesłanie do podstawowych wartości i zasad obowiązującego systemu prawnego. W pojęciu interesu publicznego, tak jak w przypadku innych klauzul generalnych, znajduje się też odesłanie do aksjologicznych podstaw obowiązującego prawa i aksjologicznych fundamentów, na których opiera się system prawa pozytywnego w Polsce. Chodzi tu między innymi o odesłania do kluczowych wartości ogólnosystemowych i pozasystemowych oraz różnego rodzaju norm, reguł i zasad pozasystemowych (norm moralnych, zwyczajów, norm wiedzy, normatywów technicznych, zasad prakseologicznych itd.). Prawidłowość wykładni klauzul generalnych podlega kontroli sądowoadministracyjnej.

43 Zob. M. Zdyb, Prawny interes jednostki.., s. 215; idem, Miejsce jednostki w porzadku państwa. Państwo a jednostka, „Annales UMCS. Sectio G” 1992, Vol. 38; idem, Interes jednostki a interes publiczny..., s. 299-307.

${ }_{44}$ Zob. idem, Prawny interes jednostki..., s. 215. 
Z punktu widzenia stosowania klauzuli interesu publicznego ważne znaczenie ma też zasada proporcjonalności. Wskazuje ona na to, że ograniczenia praw i wolności, między innymi ze względu na interes publiczny, nie mogą być nadmierne, tzn. że powinny być brane pod uwagę tylko w zakresie, w jakim to jest konieczne.

Spośród możliwych środków działania - orzekł Trybunał Konstytucyjny w wyroku z dnia 25 lutego 1999 r., K 23/98 - należy wybierać możliwie najmniej uciążliwe dla podmiotów, wobec których mają być zastosowane, lub dolegliwe w stopniu nie większym niż jest to niezbędne dla osiągnięcia założonego celu. Trybunał Konstytucyjny nie widzi potrzeby odstąpienia od dotąd prezentowanego stanowiska. W sprawie K 11/94 Trybunał stwierdził między innymi, iż rozważanie, czy zakaz ten nie został naruszony przez ustawodawcę, uwzględniać powinno specyfikę poszczególnych praw jednostki. $\mathrm{Z}$ istoty tych praw powinny wynikać granice dopuszczalnych ograniczeń. Istotne w takim stanie rzeczy wydaje się udzielenie odpowiedzi na pytania: 1) czy wprowadzona regulacja ustawodawcza służy i jest konieczna dla ukształtowania ładu prawnego w sferze stosunków własnościowych, 2) czy zamierzony przez ustawodawcę cel jest możliwy do osiągnięcia bez naruszenia podstawowych standardów prawnych wyrażających istotę praw, których dotyczy, 3) czy regulacja jest niezbędna dla ochrony interesu publicznego (powszechnego), z którym jest powiązana (na który powołuje się art. 1 Protokołu nr 1 do Konwencji o Ochronie Praw Człowieka i Podstawowych Wolności), 4) czy efekt wprowadzonej regulacji pozostaje w proporcji do ciężarów nakładanych przez nią na obywatela ${ }^{45}$.

Problem stosowania zasady proporcjonalności przy korzystaniu z pojęcia interesu publicznego był przedmiotem analiz Trybunału Konstytucyjnego w szeregu innych wyroków ${ }^{46}$.

Na marginesie klauzuli generalnej interesu publicznego mogą się rodzić pewne dylematy co do tego, jak się mają do siebie pojęcia interesu publicznego do pojęcia dobra wspólnego. Oba pojęcia są używane w rozdziale I pt. Rzeczypospolita Konstytucji RP z 1997 r. Do problemów z tym związanych próbował odnieść się Trybunał Konstytucyjny. W wyroku z dnia 25 listopada 2003 r. przyjął, że:

45 Wyrok TK z dnia 25 lutego 1999 r., K 23/98, OTK ZU 1999/2/25.

46 Warto zwrócić uwagę chociażby na takie wyroki (przed 1997 r. były to orzeczenia) Trybunału Konstytucyjnego, jak: wyrok TK z dnia 8 kwietnia 1998 r., sygn. K 10/97, OTK ZU 1998/3/29; wyrok TK z dnia 9 czerwca 1998 r., sygn. K 28/97, OTK ZU 1998/4/50; wyrok TK z dnia 26 kwietnia 1999 r., sygn. K 33/98, OTK ZU 1994/4/97; wyrok TK z dnia 11 maja 1999 r., sygn. K 13/98, OTK ZU 1999/4/74; wyrok TK z dnia 11 kwietnia 2000 r., sygn. K 15/98, OTK ZU 2000/3/86; wyrok TK z dnia 29 czerwca 2001 r., sygn. K 23/00, OTK ZU 2003/9A/103; wyrok TK z dnia 29 stycznia 2002 r., sygn. K 19/01, OTK ZU 2002/1A/1; wyrok TK z dnia 17 grudnia 2003 r., sygn. SK 15/03, OTK ZU 2004/4A/31; wyrok TK z dnia 17 grudnia 2003 r., sygn. SK 15/02, OTK ZU 2003/9A/103; wyrok TK z dnia 21 kwietnia 2004 r., sygn. K 33/03, OTK ZU 2004/4A/31; wyrok TK z dnia 22 września 2005 r., sygn. Kp 1/05, OTK ZU 2005/8A/93; wyrok TK z dnia 11 kwietnia 2006 r., sygn. SK 57/04, OTK ZU 2006/SA/43; wyrok TK z dnia 25 lipca 2006 r., sygn. P 24/05, OTK ZU 2006/7A/97; wyrok TK z dnia 6 grudnia 2006 r., sygn. SK 5/05, OTK ZU 2006/11A/169; wyrok TK z dnia 26 marca 2007 r., sygn. K 29/06, OTK ZU 2007/3A/30; wyrok TK z dnia 22 września 2002, sygn. K 19/01, OTK ZU 2002/1A/1; wyrok TK z dnia 20 lutego 2008 r., sygn. K 39/07, OTK ZU 2007/8A/41; wyrok TK z dnia 8 lipca 2008 r., sygn. K 45/07, OTK ZU 2009/1 A/3 itd. 
Obronność, jako wartość polegająca na tworzeniu systemu zapewniającego bezpieczne funkcjonowanie państwa w trakcie pokoju oraz umożliwiającego odparcie jakichkolwiek ataków zbrojnych w trakcie działań o charakterze agresji militarnej, należy do tych wartości, których realizacja należy do podstawowych interesów państwa. Zapewnienie bezpieczeństwa kraju stanowi jeden z zasadniczych obowiązków obywateli, co wynika już z art. 1 Konstytucji, zgodnie z którym Polska jest dobrem wspólnym wszystkich obywateli. Troska o to wspólne dobro oznacza konieczność ponoszenia takich obowiązków przez obywateli, zarówno pośrednio, jak i bezpośrednio, które są niezbędne dla zapewnienia bezpieczeństwa państwa. [...] Realizacja wskazanego powyżej obowiązku państwa stania na straży niepodległości i nienaruszalności terytorium może nastąpić, a w pewnych okolicznościach niewątpliwie musi, inter alia przez stworzenie mechanizmów ingerujących w realizację niektórych podlegających konstytucyjnej ochronie praw podmiotowych i wolności obywateli i innych podmiotów. Słusznie podkreślono w wyroku z 16 lutego 1999 r., SK 11/98 (OTK ZU nr 2/1999, poz. 22), iż prawa jednostki zderzają się w tym przypadku z celowością ochrony dobra wspólnego związanego ściśle z ochroną bezpieczeństwa państwa, a więc z tą wartością, która w każdym demokratycznym porządku prawnym może, w granicach wyznaczonych niezbędnością, uzasadniać wkroczenie w prawa jednostki, nawet w prawa podstawowe [...]. Ingerencja ta może mieć różną postać, zawsze jednak powinna być dokonywana w ramach obowiązującego prawa, w tym przede wszystkim z uwzględnieniem wartości konstytucyjnych. Wprowadzenie odpowiednich mechanizmów ustawowych w tym zakresie nie może prowadzić do naruszenia tych wartości i powinno respektować zasadę proporcjonalności, wyrażoną w art. 31 ust. 3 Konstytucji ${ }^{47}$.

Mając to na uwadze, uważamy, że „dobro wspólne Rzeczypospolitej jest dobrem wszystkich obywateli. Jest wartością ponadjednostkową, ukierunkowaną na działania i cele jednostek. Jest też wartością nadrzędną, w tym znaczeniu, że integruje inne wartości, w tym też te, które są konsekwencją poszczególnych praw i wolności obywatelskich"48.

W tekście tego zdania odrębnego zostały wskazane także inne elementy wyrażające istotę dobra wspólnego w kontekście pojęcia interesu publicznego. M. Zdyb podkreśla w nim, że

Zasady tej nie można odrywać od aksjologicznej perspektywy, do której jest odnoszona, w przeciwnym bowiem razie łatwo można dojść do pesymistycznej i zrelatywizowanej do niższych wartości wizji i kategorii demokracji sceptycznej. Dobro wspólne krystalizuje się nie tylko $\mathrm{w}$ formalnie pojmowanym zbiorze norm i zasad - choćby konstytucyjnych - i w proceduralnej ochronie praw i wolności, ale i w takim pojmowaniu tychże praw, gdzie traktuje się je jako sztukę tego, co dobre i słuszne. Konstytucja tworzy pewną całość. Niedopuszczalne jest takie przemieszanie celów, środków i wartości konstytucyjnych, gdzie każda z nich żyje własnym życiem albo wyrasta bez należytego aksjologicznego uzasadnienia ponad inne. Włodarz dobra wspólnego, o ile jest to uprawnione koniecznością zabezpieczenia bardzo ważnych wartości, takich chociażby, o jakich mowa w art. 5 Konstytucji - a tak jest w niniejszym przypadku - może żądać ofiar z zasad konstytucyjnie chronionych na rzecz innych wartości konstytucyjnych. Dobro wspólne zabezpieczane jest przede wszystkim przez odpowiednie organy państwa, w tym też organy uprawnione do stanowienia prawa. Organy te $-\mathrm{w}$ określonych sytuacjach - jeżeli tego

47 Wyrok TK z dnia 25 listopada 2003 r., sygn. K 37/02,OTK ZU 2003/9A/96.

48 Zdanie odrębne M. Zdyba do wyroku TK z dnia 10 października 2001 r., sygn. K 28/01, OTK ZU 2001/7/212. 
wymaga ochrona dobra wspólnego, nie tylko mogą, ale i mają obowiązek wprowadzenia ograniczeń w korzystaniu z wolności, jeżeli jest to konieczne dla takiej ochrony. [...] Zakres realizacji praw i wolności konstytucyjnie chronionych mieści się w przedziale, dla którego aksjologiczne granice określa treść art. 30 (godność człowieka) i art. 1 Konstytucji (dobro wspólne). Oba te przepisy mogą determinować swoistą hierarchię praw i wolności. Z pierwszego z nich wynika przede wszystkim obowiązek zachowania państwa, należyta troska o jego suwerenność, konieczność zagwarantowania ładu publicznego i bezpieczeństwa obywateli. W konsekwencji oznacza to także zabezpieczenie realizacji podstawowych i fundamentalnych praw człowieka. Wartość ta usprawiedliwiać może - co też wielokrotnie ustrojodawca czyni - potrzebę ograniczenia innych wartości społecznych, wolności obywatelskich i zasad konstytucyjnie chronionych, zwłaszcza gdy mają one jedynie proceduralne odniesienie ${ }^{49}$.

\section{Reasumując,}

[...] należałoby stwierdzić, że dobro wspólne jest uosobieniem wartości fundamentalnych dla ładu publicznego w państwie i jego bezpieczeństwa. Są to wartości, które bez względu na faktyczne odniesienia, mają swoje odniesienia w kulturze prawnej i w tym sensie mają znaczenie ponadczasowe. Nie można go odrywać od wartości podstawowych, sprawiedliwości, prawdy, moralności, a także podstawowych praw i wolności. Stąd należy go widzieć nie tylko w płaszczyźnie ekonomicznej, politycznej czy normatywnej, ale i także w kontekście odniesień historycznych, ontologicznych i metafizycznych ${ }^{50}$.

\section{BIBLIOGRAFIA}

Blicharz J., Kategoria interesu publicznego jako przedmiot działania administracji publicznej, „Acta Universitatis Wratislaviensis. Przegląd Prawa i Administracji” 2004, t. 40.

Blicharz R., Kania M., Klauzula interesu publicznego w publicznym prawie gospodarczym, „Przegląd Ustwodawstwa Gospodarczego" 2010, nr 5.

Dobkowski J., Kategoria interesu publicznego jako przedmiot regulacji ustawy o planowaniu i zagospodarowaniu przestrzennym, [w:] Planowanie strategiczne i przestrzenne, red. R. Biskup, A. Haładyj, „Prawo - Administracja - Kościół” 2006 (nr specjalny).

Góral L., Interes publiczny jako przesłanka ingerencji państwa w sferę funkcjonowania rynku bankowego w Polsce $i$ we Francji, „Studia Prawno-Ekonomiczne” 2010, t. 82.

Góral L., Zintegrowany model publicznoprawnych instytucji ochrony rynku bankowego we Francji i Polsce, Warszawa 2011.

Lang J., Z rozważań nad pojęciem interesu w prawie administracyjnym, [w:] Przeobrażenia we wspótczesnym prawie administracyjnym $i$ w nauce administracji, red. A. Błaś, „Acta Universitatis Wratislaviensis. Przegląd Prawa i Administracji” 1997, t. 38.

Leszczyński L., Kategoria interesu w stosowaniu prawa administracyjnego. Przykład art. 7 KPA, [w:] Pojęcie interesu w naukach prawnych, prawie stanowionym i orzecznictwie sadowym Polski i Ukrainy, red. A. Korybski, M.W. Kostyckij, L. Leszczyński, Lublin 2006.

Leszczyński L., Rozdziat II. Podstawa decyzji stosowania prawa administracyjnego. Ustalenia walidacyjne, [w:] System Prawa Administracyjnego, t. 4: Wykładnia w prawie administracyjnym, red. R. Hauser, Z. Niewiadomski, A. Wróbel, Warszawa 2012.

49 Ibidem. Zob. także: M. Zdyb, Komentarz do art. 6 ustawy z 2 lipca 2004 r. o swobodzie działalności gospodarczej, [w:] M. Zdyb, M. Sieradzka, Ustawa o swobodzie działalności gospodarczej..., s. 145 i n.

${ }_{50}$ Zob. M. Zdyb, M. Sieradzka, Ustawa o swobodzie działalności..., s. 146 i n. 
Leszczyński L., Rozdział VII. Interpretacyjna rola kryteriów otwartych i innych decyzji stosowania prawa, [w:] System Prawa Administracyjnego, t. 4: Wykładnia w prawie administracyjnym, red. R. Hauser, Z. Niewiadomski, A. Wróbel, Warszawa 2012.

Leszczyński L., Stosowanie generalnych klauzul odsyłajacych, Kraków 2001.

Leszczyński L., Tworzenie generalnych klauzul odsyłających, Lublin 2000.

Modliński E., Pojęcie interesu publicznego w prawie administracyjnym, Warszawa 1932.

Ustawa z dnia 14 czerwca 1960 r. - Kodeks postępowania administracyjnego (t.j. Dz.U. z 2013 r., poz. 267 z późn. zm.).

Ustawa z dnia 29 grudnia 1992 r. o radiofonii i telewizji (t.j. Dz.U. z 2011 r., nr 43, poz. 226 z późn. zm.).

Ustawa z dnia 29 sierpnia 1997 r. - Prawo bankowe (t.j. Dz.U. z 2015 r., poz. 128).

Ustawa z dnia 27 marca 2003 r. o planowaniu i zagospodarowaniu przestrzennym (t.j. Dz.U. z 2015 r., poz. 199).

Ustawa z dnia 2 lipca 2004 r. o swobodzie działalności gospodarczej (t.j. Dz.U. z 2013 r., poz. 672 z późn. zm.).

Ustawa z dnia 21 lipca 2006 r. o nadzorze nad rynkiem finansowym (t.j. Dz.U. z 2012 r., poz. 1149 z późn. zm.).

Ustawa z dnia 4 marca 2010 r. o świadczeniu usług na terytorium Rzeczypospolitej Polskiej (Dz.U., nr 47 , poz. 278 z późn. zm.).

Wołpiuk W.J., Dobro wspólne a interes publiczny, „Zeszyty Naukowe Wyższej Szkoły Informatyki, Zarządzania i Administracji w Warszawie” 2006, z. 1.

Wyrok NSA z dnia 17 lipca 2009 r., II FSK 2137/08, Legalis.

Wyrok TK z dnia 8 kwietnia 1998 r., sygn. K 10/97, OTK ZU 1998/3/29.

Wyrok TK z dnia 8 kwietnia 1998 r., sygn. K 10/97, OTK ZU 1998/55/363.

Wyrok TK z dnia 9 czerwca 1998 r., sygn. K 28/97, OTK ZU 1998/4/50.

Wyrok TK z dnia 12 stycznia 1999 r., sygn. P. 2/98, OTK ZU 1999/1/1.

Wyrok TK z dnia 25 lutego 1999 r., K 23/98, OTK ZU 1999/2/25.

Wyrok TK z dnia 26 kwietnia 1999 r., sygn. K 33/98, OTK ZU 1994/4/97.

Wyrok TK z dnia 11 maja 1999 r., sygn. K 13/98, OTK ZU 1999/4/74.

Wyrok TK z dnia 14 czerwca 1999 r., sygn. K 11/09; OTK ZU 1999/5/97.

Wyrok TK z dnia 11 kwietnia 2000 r., sygn. K 15/98, OTK ZU 2000/3/86.

Wyrok TK z dnia 29 czerwca 2001 r., sygn. K 23/00, OTK ZU 2003/9A/103.

Wyrok TK z dnia 29 stycznia 2002 r., sygn. K 19/01, OTK ZU 2002/1A/1.

Wyrok TK z dnia 22 września 2002, sygn. K 19/01, OTK ZU 2002/1A/1.

Wyrok TK z dnia 25 listopada 2003 r., sygn. K 37/02,OTK ZU 2003/9A/96.

Wyrok TK z dnia 17 grudnia 2003 r., sygn. SK 15/02, OTK ZU 2003/9A/103.

Wyrok TK z dnia 17 grudnia 2003 r., sygn. SK 15/03, OTK ZU 2004/4A/31.

Wyrok TK z dnia 21 kwietnia 2004 r., sygn. K 33/03, OTK ZU 2004/4A/31.

Wyrok TK z dnia 22 września 2005 r., sygn. Kp 1/05, OTK ZU 2005/8A/93.

Wyrok TK z dnia 11 kwietnia 2006 r., sygn. SK 57/04, OTK ZU 2006/SA/43.

Wyrok TK z dnia 25 lipca 2006 r., sygn. P 24/05, OTK ZU 2006/7A/97.

Wyrok TK z dnia 6 grudnia 2006 r., sygn. SK 5/05, OTK ZU 2006/11A/169.

Wyrok TK z dnia 26 marca 2007 r., sygn. K 29/06, OTK ZU 2007/3A/30.

Wyrok TK z dnia 20 lutego 2008 r., sygn. K 39/07, OTK ZU 2007/8A/41.

Wyrok TK z dnia 8 lipca 2008 r., sygn. K 45/07, OTK ZU 2009/1A/3

Wyrok WSA w Warszawie z dnia 23 września 2005 r., IV SA/Wa 671/05, CBOSA.

Wyrok WSA w Warszawie z dnia 2 czerwca 2008 r., II SA/Wa 2125/07, Legalis.

Wyrzykowski M., ,Interes społeczny” jako kategoria proceduralna, „Acta Universitatis Wratislaviensis. Prawo" 1990, nr 1022.

Wyrzykowski M., Pojęcie interesu społecznego w prawie administracyjnym, Warszawa 1986. 
Zdanie odrębne M. Zdyba do wyroku TK z dnia 10 października 2001 r., sygn. akt K 28/01, OTK ZU 2001/7/212.

Zdyb M., Administracyjnoprawne ograniczenia praw rzeczowych, [w:] System Prawa Administracyjnego, t. 7: Materialne prawo administracyjne, red. R. Hauser, Z. Niewiadomski, A. Wróbel, Warszawa 2012.

Zdyb M., Dobro wspólne w perspektywie art. 1 Konstytucji RP, [w:] Trybunat Konstytucyjny. Księga XV-Lecia, Warszawa 2001.

Zdyb M., Drogi i bezdroża państwa prawnego, [w:] Konstytucja, ustrój, system finansowy państwa. Ksiega pamiatkowa ku czci Prof. Natalii Gajl, Warszawa 1999.

Zdyb M., Interes jednostki a interes publiczny (spoleczny). Konflikt interesów, „Annales UMCS. Sectio G" 1993, Vol. 40.

Zdyb M., Interes publiczny w orzecznictwie Trybunału Konstytucyjnego, [w:] Pojęcie interesu w naukach prawnych, prawie stanowionym i orzecznictwie sądowym Polski i Ukrainy, red. A. Korybski, M.W. Kostyckij, L. Leszczyński, Lublin 2006.

Zdyb M., Komentarz do art. 3 ustawy z dnia 16 kwietnia 1993 r. o zwalczaniu nieuczciwej konkurencji, [w:] Ustawa o zwalczaniu nieuczciwej konkurencji. Komentarz, red. M. Zdyb, M. Sieradzka, Warszawa 2011.

Zdyb M., Komentarz do art. 6 ustawy z 2 lipca 2004 r. o swobodzie działalności gospodarczej, [w:] M. Zdyb, M. Sieradzka, Ustawa o swobodzie działalności gospodarczej. Komentarz, Warszawa 2013.

Zdyb M., Miejsce jednostki w porządku państwa. Państwo a jednostka, „Annales UMCS. Sectio G” 1992, Vol. 38.

Zdyb M., Ochrona interesu indywidualnego w sferze prawa administracyjnego. Jednostka w systemie normatywnych uwarunkowań państwa prawnego, „Folia Societatis Scientarum Lublinensis" 1990, Vol. 32.

Zdyb M., Państwo prawa w perspektywie zaszłości historycznych oraz dokonujacych się zmian, [w:] Wspótczesne problemy prawa publicznego, red. S. Fundowicz, Lublin 1999.

Zdyb M., Prawny interes jednostki w sferze materialnego prawa administracyjnego, Lublin 1991.

Zdyb M., Wspólnotowe i polskie publiczne prawo gospodarcze, t. 1: Wolność i reglamentacja dziatalności gospodarczej. Handel zagraniczny, Warszawa 2008.

Zdyb M., Zasady ogólne kodeksu postępowania administracyjnego jako fundament kształtowania wspótczesnego tadu konstytucyjnego, [w:] Kodyfikacja postępowania administracyjnego na 50-lecie K.P.A., red. J. Niczyporuk, Lublin 2010.

Zdyb M., Sieradzka M., Interpretacja treści klauzuli generalnej pojęcia czynu nieuczciwej konkurencji $w$ świetle innych przepisów ustawy o zwalczaniu nieuczciwej konkurencji, „Przegląd Prawa Handlowego" 2011, nr 12.

Zdyb M., Sieradzka M., Ustawa o swobodzie działalności gospodarczej. Komentarz, Warszawa 2013.

Zdyb M., Stelmasiak J., Szreniawski J., Zasada proporcjonalności w świetle Konstytucji RP, [w:] Podmioty administracji publicznej i prawne formy ich działania. Studia i materiały z konferencji jubileuszowej Profesora Eugeniusza Ochendowskiego, Torun 2005.

Żurawik A., „Interes publiczny”, ,,interes społeczny” $i$,,interes społecznie uzasadniony”. Próba dookreślenia pojęć, „Ruch Prawniczy, Ekonomiczny i Socjologiczny” 2013, nr 2.

Żurawik A., Klauzula interesu publicznego w prawie gospodarczym krajowym i unijnym, „Europejski Przegląd Sądowy” 2012, nr 12. 


\section{SUMMARY}

Nowadays public interest clause is taken as indissolubly connected with public administration and its activity. Among other things it is used to describe, to qualify and define what is public administration itself and in what kind of matters its essence consist in. Public interest is a fundamental, pivotal notion in administrative law, but still - in spite of attempts undertaken even by the legislator to define this notion - it is not understood univocally. Public interest clause is a normative structure, it is a reference general clause. The most generally speaking, it is a directive applied to public administration organs, which should accomplish their tasks in the public interest. Public interest clause is reckoned among fundamental clauses for administrative law (meta-clauses), but it does not mean an ackowledgement of absolute primacy for public interest in public administration activity. One should remember about adequate weigh of public interest and interest of citizen (particularistic interest, interest of individual, individual interest), because there are specified, fundamental human rights and even there is an opinion that the notion of public interest acquires importance and gathers full of its content only if it is set together with the right/interest of individual.

Keywords: public administration; public interest; interest of citizen; particularistic interest; interest of individual; individual interest

\section{STRESZCZENIE}

Klauzula interesu publicznego jest współcześnie traktowana jako nierozerwalnie związana $\mathrm{z}$ administracją publiczną i jej działaniami. Wykorzystuje się ją między innymi podczas prób określenia, czym jest sama administracja publiczna i na czym polega jej istota. Interes publiczny jest pojęciem kluczowym na gruncie prawa administracyjnego, lecz nadal - mimo podejmowanych nawet przez ustawodawcę prób zdefiniowania tego pojęcia - nie jest ono rozumiane jednoznacznie. Klauzula interesu publicznego jest konstrukcją normatywną, o charakterze generalnej klauzuli odsyłającej. Najogólniej rzecz ujmując, jest ona dyrektywą kierowaną do organów administracji publicznej, które swoje zadania powinny wykonywać w interesie publicznym. Klauzula interesu publicznego jest zaliczana do klauzul zasadniczych dla prawa administracyjnego (meta-klauzul), co nie oznacza przyznania absolutnego prymatu interesowi publicznemu w działaniach administracji publicznej. Należy pamiętać o odpowiednim ważeniu interesu publicznego interesem obywatela (interesem jednostki, interesem indywidualnym), istnieją bowiem określone, zasadnicze prawa człowieka, a nawet można spotkać poglądy, iż pojęcie interesu publicznego nabiera pełnej treści dopiero wtedy, gdy zostanie on zestawiony z prawem poszczególnej jednostki.

Słowa kluczowe: administracja publiczna; interes publiczny; interes obywatela; interes indywidualny; interes jednostki 